\title{
Effect of Liquidity, Asset Management, Leverage and Dividend Policy on Firm Value at Food and Beverages Companies Listed on the Indonesia Stock Exchange
}

\author{
Andreas $^{1}$, Christin ${ }^{2}$, Shelly Wijaya ${ }^{3}$, Jessi Charina Sembiring ${ }^{4}$ \\ 1,2,3,4 Universitas Prima Indonesia, Indonesia \\ andreassaerdna8@gmail.com
}

\begin{abstract}
This study aims to analyze the effect of liquidity, asset management, leverage and dividend policy on firm value at Food and Beverages Companies listed on the Indonesia Stock Exchange. The type of research used is quantitative research because the data used is numbers while the nature of this research is descriptive research. The population in this study amounted to 30 Food and Beverages Companies listed on the Indonesia Stock Exchange. The research sample used is in the form of financial statements of Food and Beverages Companies listed on the Indonesia Stock Exchange with a total of 20 companies from 2016-2019. The results of this study indicate that the current ratio, total asset turnover, debt to equity ratio and dividend payout ratio have a positive and significant effect on firm value at Food and Beverages Companies.
\end{abstract}

Keywords

current ratio, total asset turnover, debt to equity ratio, dividend payout ratio, firm value

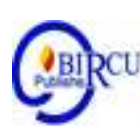

\section{Introduction}

A company is an organization established by an individual or group of people or other bodies whose activities are to carry out production and distribution in order to meet the current economic needs of humans. The form of a company's performance is inseparable from planning in which there are various company goals that are planned, both in the long and short term. Where the main goal of each company is to maximize profits, strive for growth and ensure the survival of the company. The short-term goal of the company is to get maximum profit from existing resources. Meanwhile, in the long term the main objective of the company is to maximize company value.

Company value is a certain condition that has been achieved by a company as a reflection of public trust in the company after going through a process of activity for several years from the time the company was founded to the present. A high company value indicates that the shareholder's prosperity is also high. There are many factors that influence firm value including liquidity, asset management, leverage and dividend policy. Liquidity is one of the factors that affect firm value. Liquidity is the company's ability to meet its short-term liabilities by using its current assets. When a company is unable to pay its obligations, especially short-term debt (which is due), it is caused by several factors, namely the company does not have funds at all or the company has funds, but when the funds are due, the funds are not enough to pay the debt in cash so they have to wait in time. certain to redeem other assets such as collecting receivables and selling marketable securities. Companies that have a high level of liquidity will indicate that the growth of a company tends to be high. The more liquid the company is, the higher the creditor's level of confidence in providing funds. This is an attraction for investors to own company shares and will increase the share price so that the company's value increases. 
Another factor that can also affect the value of the company is the asset management ratio to measure the effectiveness of a company in operating its funds, which uses the asset management ratio. The use of asset management ratios is to compare the level of sales with investment in assets in one period. That is, it is expected that there will be a balance as desired between sales and assets such as inventories, accounts receivable and other fixed assets. Based on the measurement results of asset management ratios, it will be seen whether the company is more efficient and effective in managing its assets or vice versa. Effective and efficient company activities can affect the company's profit and cash flow so that it will add value to the company.

Another factor that can also affect firm value is leverage. Solvency (leverage) is described to see the extent to which the company's assets are financed by debt compared to its own capital (Analisa, 2011). Leverage can be understood as an estimate of the risk inherent in a company. This means that the greater the leverage indicates that the greater the investment risk. Companies with low leverage ratios have less leverage risk. Therefore, if investors see a company with high assets but high leverage risk, they will think twice about investing in that company. Because it is feared that these high assets will be obtained from debt which will increase investment risk if the company is unable to pay off its obligations on time. The high leverage ratio shows that the company is not solvable, where its total debt is greater than its total assets (Analisa, 2011).

In addition to liquidity, asset management and leverage, dividend policy in which investors have the main objective to improve welfare by expecting returns in the form of dividends and capital gains, while the company expects continuous growth to maintain its survival while providing welfare to its shareholders (Afzal and Rohman, 2012). Dividend policy is proxied in the form of dividend payout ratio (DPR). Dividend payout ratio is the percentage of profit paid to shareholders in cash. In dividend distribution decisions, it is necessary to consider the survival and growth of the company. For investors who invest, of course, the rate of return or profit that will be obtained from their investment is in the form of capital gains and dividends which are part of the profits given to shareholders.

Based on the data experiencing fluctuation (increase and decrease). Among them happened at PT. Indofood CBP Sukses Makmur Tbk., current assets in 2017 amounted to Rp16,579,331, an increase compared to 2016 which amounted to Rp15,571,362 and the stock price in 2017 was Rp8,900, an increase compared to 2016 which was Rp8,575. For 2018 Net Sales of Rp38,413,407, an increase compared to 2017 of Rp35,606,593 and the share price in 2018 of Rp10,450, an increase compared to 2017 of Rp8,900. For total debt in 2019 amounting to Rp12,038,210 has increased compared to 2018 of Rp11,660,003 and the share price in 2019 was Rp11,175, an increase compared to 2018 of Rp10,450. For dividends per share in 2017 amounting to Rp162, an increase compared to Rp154 in 2016. At PT. Indofood Sukses Makmur Tbk., current assets in 2017 amounted to Rp32,515,399, an increase compared to 2016 amounting to Rp28,985,443 and the share price in 2017 was

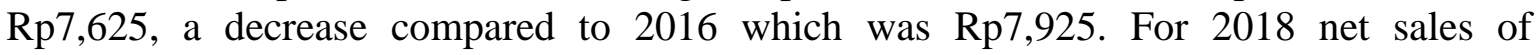
Rp73,394,728, an increase compared to 2017 of Rp70,186,618 and the share price in 2018 of Rp7,450 has decreased compared to 2017 of Rp7,625. For total debt in 2019 amounting to Rp41,996,071 has decreased compared to 2018 which amounted to Rp46,620,996 and the share price in 2019 was Rp7,925, an increase compared to 2018 which was Rp7,450. For dividends per share in 2017 amounting to Rp237, an increase compared to Rp235 in 2016. At PT. Unilever Indonesia Tbk., current assets in 2017 amounted to Rp7,941,635, an increase compared to 2016 which amounted to Rp6,588,109 and the share price in 2017 of Rp11,180 has increased compared to 2016 of $\mathrm{Rp7} 760$. For 2018 net sales of Rp41,802,073, an increase compared to 2017 of Rp41,204,510 and the share price in 2018 
of Rp9,080 experienced a decrease compared to 2017 of Rp11,180. Total debt in 2019 amounted to Rp15,367,509, an increase compared to 2018 of Rp11,944,837 and the share price in 2019 of $\mathrm{Rp} 8,560$ experienced a decrease compared to 2018 of $\mathrm{Rp} 9,080$. For dividends per share in 2017 amounting to Rp505, an increase compared to 2016 which amounted to Rp460.

\section{Review of Literature}

\subsection{Effect of Liquidity on Firm Value}

According to Harahap (2011), the liquidity ratio describes a company's ability to settle its short-term obligations. This means that if the company is billed, the company will be able to meet the debt, especially debt that is due. This ratio can be calculated through sources of information on working capital, namely current assets and current liabilities. According to Brigham and Houston (2012), one measure of a company's liquidity is the current ratio. This ratio shows the extent to which current liabilities are covered by assets that are expected to be converted into cash in the near future. The greater the ratio of current assets to current debt, the higher the company's ability to cover its short-term liabilities. If the company is having trouble.

\subsection{Effect of Asset Management on Firm Value}

Menuurt Brigham and Houston (2012) state that the activity ratio can also be called the asset management ratio. Asset management ratios measure how effectively a company manages its assets. This ratio answers the question, whether the amount of each type of asset looks reasonable, too high or too low when viewed from current sales. If the company has too many assets, then the cost of capital is too high and profits will be depressed and if the assets are too low, profitable sales will not be achieved or lost. According to Sumarsan (2013: 49), the activity ratio is used to measure the speed of asset estimates in the statement of financial position to generate sales and ultimately cash.

\subsection{Effect of Leverage on Firm Value}

According to Harahap (2011), leverages describe the relationship between company debt to capital and assets. This ratio looks at how far the company is financed by debt or external parties with the company's capabilities as described by capital. A good company should have a larger capital composition than debt. According to Kasmir (2012:151), the leverage ratio is a ratio used to measure the extent to which the company's assets are financed with debt, meaning how much debt the company bears compared to its assets.

\subsection{Effect of Dividend Policy on Firm Value}

According to Husnan (2013) dividend policy is a decision related to the use of profit which is the right of shareholders and this profit can be divided as dividends or retained earnings to be reinvested. According to Sudana (2015), dividend policy is related to determining the amount of the dividend payout ratio, which is the percentage of net profit after tax which is distributed as dividends to shareholders. 


\section{Research Methods}

The research approach used is quantitative research. According to Sugiyono (2017:7) quantitative research is research data in the form of numbers and analysis using statistics. The type of research used is based on the philosophy of positivism. According to Sugiyono (2017:8) the philosophy of positivism is used to research on certain populations or samples, data collection using research instruments, data analysis is quantitative/statistical, with the aim of testing predetermined hypotheses. The nature of this research is deductive. According to Sugiyono (2017:8) deductive research is to answer the problem formulation using a concept or theory so that a hypothesis can be formulated. The hypothesis is then tested through data collection. The data that has been collected is then analyzed quantitatively using descriptive statistics so that it can be concluded that the formulated hypothesis is proven or not.

According to Sugiyono (2017:80) population is a generalization area consisting of objects/subjects that have certain qualities and characteristics that are determined by researchers to study and draw conclusions. The population that will be used in this study is a food and beverage company in the Indonesia Stock Exchange for the 2016-2019 period, amounting to 28 companies. According to Sugiyono (2017:81) the sample is part of the number and characteristics of the population. This research uses purposive sampling technique.

The total number of observational data used in this study is 80 samples taken from a total sample of 20 companies multiplied by 4 periods of the study. In this study, the data analysis method used is the statistical analysis method using SPSS 20 software. Before the data is analyzed, for the purposes of analyzing the data, a classical assumption test is first performed before testing the hypothesis. To test the hypothesis, multiple linear regression analysis was carried out.

\section{Results and Discussion}

\subsection{Descriptive Statistics}

The research sample used is the financial statements of companies in the Food \& Beverages sector listed on the IDX totaling 20 companies from 2016-2019. There are as many as 10 outliers in the research data so they must be eliminated and the final total sample used is $80-10=70$ samples.

The variable current ratio $(\mathrm{CR})\left(\mathrm{X}_{1}\right)$ is known that the average of all samples is 0.4394 with a standard deviation of 0.93743 , the lowest value is -3.91 and the highest value is 2.16. The variable total asset turnover (TATO) $\left(\mathrm{X}_{2}\right)$ shows that the average of all samples is -0.3580 with a standard deviation of 0.93984 , the lowest value is -3.00 and the highest value is 1.13 . The debt to equity ratio (DER) $\left(\mathrm{X}_{3}\right)$ variable shows that the mean of all samples is 1.2061 with a standard deviation of 0.31823 , the lowest value is 0 and the highest value is 1.87 . The variable dividend payout ratio (DPR) $\left(\mathrm{X}_{4}\right)$ shows that the average of all samples is 0.1693 with a standard deviation of 0.21346 , the lowest value is 0 and the highest value is 0.86 . The variable stock price $(\mathrm{Y})$ shows that the average of all samples is 6,360 with a standard deviation of 1.49611, the lowest value is 3.91 and the highest value is 9.25 . 


\subsection{Determination Coefficient ( $\mathrm{R} 2)$}

The coefficient of determination is intended to determine how much the dependent variable is influenced by the independent variable. If the coefficient of determination is greater or closer to 1 , then the effect of the independent variable on the dependent variable is getting bigger.

Table 1. Determination Coefficient Model Summary ${ }^{b}$

\begin{tabular}{|l|l|r|r|r|}
\hline Model & R & R Square & $\begin{array}{c}\text { Adjusted R } \\
\text { Square }\end{array}$ & $\begin{array}{c}\text { Std. Error of } \\
\text { the Estimate }\end{array}$ \\
\hline 1 & $.740^{\mathrm{a}}$ & .548 & .520 & 1.03617 \\
\hline
\end{tabular}

a. Predictors: (Constant), DPR, CR, TATO, DER

b. Dependent Variable: Stock Price

To test the coefficient of determination of more than two variables, the adjusted $\mathrm{R}$ square value is used, namely 0,520 or $52 \%$, which means the variable current ratio $\left(\mathrm{X}_{1}\right)$, total asset turn over $\left(\mathrm{X}_{2}\right)$, debt to equity ratio $\left(\mathrm{X}_{3}\right)$, devidend payout ratio $\left(\mathrm{X}_{4}\right)$ can affect the variable stock price by $52 \%$ and the remaining $48 \%$ is influenced by other variables.

\subsection{Partial Statistical Test (t Test)}

$\mathrm{t}$ test is used to determine how the independent variable affects the dependent variable individually. It is said to have a significant effect if the significant value is $<0.05$. It can be seen through the table of data processing results below:

Table 2. $t$ Test

Coefficients $^{\mathrm{a}}$

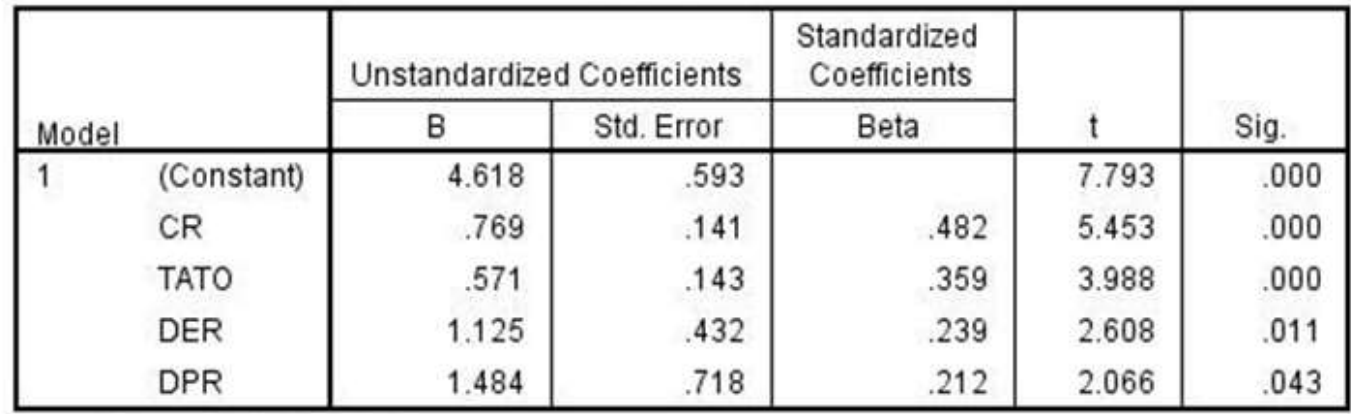

a. Dependent Variable: Stock Price

The results of statistical tests can be explained as:

1. Current ratio variable obtained $t_{\text {count }} 5.453>1.998$ and a significant value of $0.000<$ 0.05 , so partially the current ratio variable has a significant and significant effect on stock price.

2. Total asset turnover variable obtained $t_{\text {count }} 3.988>1.998$ and a significant value of $0.000<0.05$, so partially the total asset turn over variable has a significant and significant effect on stock price.

3. Debt to equity ratio variable obtained $t_{\text {count }} 2.608>1.998$ and a significant value of 0 , $011<0.05$, so partially the debt to equity ratio variable has a significant and significant effect on stock price. 
4. Devidend payout ratio variable obtained $t_{\text {count }} 2.066>1.998$ and a significant value of $0.043<0.05$ so partially the variable devidend payout ratio has a significant and significant effect on stock price.

\subsection{Simultaneous Significance Test (F Test)}

The F test is used to show whether all the independent variables included in the model have a simultaneous (simultaneous) influence on the dependent variable. It can be said to affect simultaneously if the value of $F_{\text {count }}>F_{\text {table }}$ and the significance value $<0.05$ and the table of data processing results can be seen through the following SPSS application:

Table 3. F Test

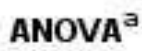

\begin{tabular}{|ll|r|r|r|r|r|}
\hline Model & & $\begin{array}{l}\text { Sum of } \\
\text { Squares }\end{array}$ & df & Mean Square & F & Sig. \\
\hline 1 & Regression & 84.658 & 4 & 21.165 & 19.713 & $.000^{\circ}$ \\
& Residual & 69.788 & 65 & 1.074 & & \\
& Total & 154.446 & 69 & & & \\
\hline
\end{tabular}

a. Dependent Variable: Harga Saham

b. Predictors: (Constant), DPR, CR, TATO, DER

Based on Table 3 above, it shows that $\mathrm{F}_{\text {table }}=\mathrm{F}(\mathrm{k} ; \mathrm{n}-\mathrm{k})=\mathrm{F}(4 ; 66)=2.51$ (n=lots of data, $\mathrm{k}=$ number of variables). The $\mathrm{F}$ test is obtained from the $\mathrm{F}_{\text {count }}$ value of 19.713 with a significant value of 0.000 in $F_{\text {table }} 2.51$ with a significant value of 0.05 , then $F_{\text {count }}(19,713)$ $>\mathrm{F}_{\text {table }}(2,51)$ with a significant value $<0.05$ then $\mathrm{H}_{0}$ is rejected, $\mathrm{H}_{\mathrm{a}}$ is accepted, which means that the variable current ratio $\left(\mathrm{X}_{1}\right)$, total asset turnover $\left(\mathrm{X}_{2}\right)$, debt to equity ratio $\left(\mathrm{X}_{3}\right)$, dividend payout ratio $\left(\mathrm{X}_{4}\right)$ simultaneously have an influence on stock price.

\section{Conclusion}

The results of this study indicate that the current ratio, total asset turnover, debt to equity ratio and dividend payout ratio have a positive and significant effect on firm value at Food and Beverages Companies.

It is recommended for companies to pay attention to the variables current ratio, total assets turn over, debt to equity ratio and devidend payout ratio because they are proven to have a significant effect on firm value. Good company value shows that good corporate finance will increase the company's value and will be in demand by investors.

Investors who want to invest should do further research on company value, if you want to invest in food and beverages companies listed on the Indonesia Stock Exchange, you can pay attention to current ratio, total asset turn over, debt to equity ratio and devidend payout ratio which affect value firm. For future researchers, it is hoped that this research can continue by including other variables and adding to the sample that has not been included in this research model so that this research can be more useful. For Universitas Prima Indonesia, it is hoped that this research can be used as reference material and additional data to conduct research related to accounting midwives. 


\section{References}

Afzal, \& Rohman, Abdul. (2012). Pengaruh Keputusan Investasi, Keputusan Pendanaan, dan Kebijakan Dividen Terhadap Nilai Perusahaan, Vol. 1, No. 2.

Analisa, Y. (2011). Pengaruh Ukuran Perusahaan, Leverage, Profitabilitas dan Kebijakan Dividen Terhadap Nilai Perusahaan (Studi Pada Perusahaan Manufaktur yang Terdaftar di BEI Tahun 2006-2008). Skripsi. UNDIP .

Brigham \& Houston. (2012). Dasar-Dasar Manajemen Keuangan. Edisi V. Jakarta: Salemba Empat.

Harahap, Sofyan Syafri. (2011). Teori Akuntansi. Edisi Revisi 2011. Jakarta: Rajawali.

Husnan, Suad. (2013). Manajemen Keuangan. Edisi Keempat. Yogyakarta: BPFE.

Kasmir. (2012). Analisis Laporan Keuangan. Jakarta: PT. Raja Grafindo Persada.

Sudana, I Made. (2015). Manajemen Keuangan Perusahaan. Edisi Kedua. Jakarta: Erlangga.

Sugiyono. (2017). Metode Penelitian Kuantitatif, Kualitatif, dan R\&D. Bandung: CV. Alfabeta.

Sumarsan, Thomas. (2013). System Pengendalian Manajemen, Konsep Aplikasi dan Pengkuran Kerja. Edisi Kedua. Cetakan 1. Jakarta: PT. Indeks. 